\begin{tabular}{l}
$\begin{array}{r}\text { Squalen Bull. of Mar. and Fish. Postharvest and Biotech. } 13 \text { (3) 2018, 124-132 } \\
\text { www.bbp4b.litbang.kkp.go.id/squalen-bulletin } \\
\text { Squalen Bulletin of Marine and Fisheries Postharvest and Biotechnology } \\
\text { ISSN: 2089-5690 } \\
\text { e-ISSN: 2406-9272 }\end{array}$ \\
\hline
\end{tabular}

SHORT COMMUNICATION

\title{
Characteristics of Solid Waste Agar Industries
}

Ifah Munifah* and Hari Eko Irianto

Research and Development Center for Marine and Fisheries Product Processing and Biotechnology Jalan KS. Tubun Petamburan VI, Slipi, Jakarta Pusat 10260, Indonesia

Article history:

Received: 24 September 2018; Revised: 7 November 2018; Accepted: 15 December 2018

\begin{abstract}
Agar processed from red seaweed Gracilaria sp. in Indonesia can be found in the form of sheet and powder. The abundance of cellulose in agar solid waste can be used as an alternative source of carbon for microorganism growth. The purpose of this study was to determine the component of agar solid waste and to characterize the cellulose. The agar solid waste (limbah industri agar-agar, LIA) was undergone physical separation process into agar, fiber cellulose, and celite. The result showed that agar solid waste consisted of $53.53 \%$ fiber; $37.33 \%$ agar and $8.60 \%$ celite. LIA was characterized for its components including ash, lignin, extractive substances, cellulose, hemicellulose, and holocellulose using Technical Association of the Pulp and Paper Industry Method (TAPPI). The TAPPI analysis revealed that solid waste generated from seaweed Gracilaria sp processing had $28.19 \%$ cellulose, $38.83 \%$ holocellulosa, $10.63 \%$ hemicellulose, $8.27 \%$ ash, $3.54 \%$ insoluble acid ash, $11.23 \%$ water, and $1.62 \%$ extractives substances. The lignin content of the solid waste was low $(2.08 \%)$, therefore it has potential to be utilized as biomass (bio fertilizer, alternative carbon source). The components in solid waste of agar was determined using Fourier Transform Infra Red (FTIR). The LIA sample had high content of celite indicated by the absorption peak which appears at wave length $2343.45 \mathrm{~cm}^{-1}$ for the $-\mathrm{Si}-\mathrm{H}$ bond and at the wave length $772.99 \mathrm{~cm}^{-1}$ for the bond $-\mathrm{Si}$ O-. Infra-red spectra showed that celite still exist in solid waste of agar. The study indicated that there was still a large amount of cellulose in the solid waste of agar.
\end{abstract}

Keywords: solid waste, cellulose, agar, lignin, celite

\section{Introduction}

The abundance of seaweed commodity, both wild and cultivated, has made Indonesia as the second largest supplier of seaweed raw materials after China (FAO, 2012). One of the processed seaweed product demonstrating the most potential and economic value is a polysaccharide. Several types of commercial seaweed polysaccharides which are currently produced from red seaweed are agar and carrageenan. Agar is a polysaccharide sulfate compound that has colloidal properties. It is widely used in various product formulations. Polysaccharide agar can be obtained from several types of red seaweed, such as Gracilaria sp. and Gelidium sp. (Stiger-Pouvreau, Bourgougnon, \& Deslandes, 2016).
Seaweed, as found in terrestrial plants, also contains cellulose. The cellulose is the largest fraction in terrestrial plants ranging from $30 \%$ to $50 \%$ of the total, whereas the cellulose fraction of seaweed was in the range of $15-28 \%$ depending on the type of seaweed (Kim et al., 2008). Seaweed cellulose has a potential to become an alternative raw material for the production of bioethanol to replace other raw materials derived from agriculture and forests. It does not compete for food purposes due to abundant availability. The production of bioethanol from seaweed waste is classified as the lignocellulosic-based ethanol (Kim, Li, Jung, Chang, \& Lee, 2011; Kim, Lee, Kim, \& Choi, 2012). The cellulosic component in agar solid waste is converted into a simple monomer sugar through a hydrolysis process. Utilization of cellulose

${ }^{*}$ Corresponding author.

E-mail: ifah_munifah@yahoo.com.au 
derived from seaweed has been widely reported, among which are Gelidium amansii, Laminaria japonica, Sargassum fulvellum, Ulva lactuca (Kim et al. 2012); Sacharina japonica (Jang, Cho, Jeong, \& Kim, 2012; Lee, Li, Lee, Ryu, \& Oh, 2013).

Red seaweed Gracilaria sp. in Indonesia is processed both traditionally and industrially into agar sheet and agar powder respectively. This processing activities produce $53 \%$ solid waste. The abundance of solid waste generated from the processing of those products raises the idea for taking advantage of the cellulose as an alternative renewable material. The purpose of this study was to determine the component of agar solid waste and also to characterize the cellulose component.

\section{Materials and Methods}

\subsection{Collection of the Samples}

The study was conducted at the Research and Development Center for Marine and Fisheries Products Processing and Biotechnology, Jakarta. The sample used was solid waste from CV. Agar Sari Jaya, an agar producer in East Java, Malang, using red seaweed Gracilaria sp. as raw material. The solid waste was actually a residual solid from the final filtration. Agar solid waste was treated by eliminating impurities as well as ground and sieved using a sieving machine to obtain 35 mesh size material. Celite was then separated.

Size reduction was performed until fine waste passing through 200 mesh sieve. The remaining agar was removed from the solid waste by heating, cooling and drying until obtaining solid waste powder free from agar. It was assayed triplicates in the form of its constituent components modified using Technical Association of the Pulp and Paper Industry Method (TAPPI) for moisture content, ash, lignin, extractive substances, insoluble acid ash, moisture content, cellulose, hemicellulose, and holocellulose.

\subsection{Lignin}

Lignin qualitative determination was conducted by discoloration of the reaction between phloroglucinolhydrochloride acid and sample. The phloroglucinolhydrochloride reagent was prepared by mixing $50 \mathrm{ml}$ of $2 \%$ phloroglucinol solution (Benzene 1-3-5-triol) in ethanol (1 $\mathrm{g}$ phloroglucinol in $50 \mathrm{~mL}$ of ethanol) with $25 \mathrm{ml}$ of $35 \%$ hydrochloride acid. Mixing with hydrochloric acid shortly before use, the solution was stored in a dark bottle with a tight lid. The presence of lignin in the sample appears as a reddish or pink violet color. The intensity of the color associated with the high or low lignin content in the sample. The lignin quantitative method was the Lignin Klason method (TAPPI T222 om-02, 2006). This method was carried out on the principle that all carbohydrates in the sample were hydrolyzed and dissolved in sulfuric acid. Unsoluble acid lignin was obtained in solid form. This value, recorded as \% lignin, ratio of lignin sample after hidrolysis to dry weight sample (whole sample).

\subsection{Holocellulosa}

The principle of this method was to degrade, dissolve lignin and obtain a carbohydrate fraction. The total carbohydrate fraction is consisting of white cellulose and hemicellulose. The extractive free timber sample equivalent of $2 \mathrm{~g}$ dried wood weight was placed in $250 \mathrm{~mL}$ Erlenmeyer, then added $80 \mathrm{~mL}$ of distilled water, $1 \mathrm{~g}$ of sodium chloride and $0.5 \mathrm{~mL}$ glacial acetic acid. The mixture was then placed in a water bath at $70^{\circ} \mathrm{C}$. The water level in the water bath was higher than the surface of the solution in the Erlenmeyer (modified from Southon \& Magana, 2010).

A total of $1 \mathrm{~g}$ sodium chloride and $0.5 \mathrm{~mL}$ of acetic acid at each 1-hour heating interval and the addition was 4 times. Filter the sample using a glass filter then washed with hot water. $25 \mathrm{~mL} 10 \%$ acetic acid was added then washed with hot water until acid free. The sample was stirred at $103 \pm 2{ }^{\circ} \mathrm{C}$ until constant weight achieved. The holocellulosa content was calculated as holocellulosa weight to dry wood weight.

\subsection{Cellulose}

Cellulose can be separated from holocellulose by dissolving hemicellulose (Southon \& Magana, 2010). A total of $2.5 \mathrm{~g}$ of agar solid waste powder was placed in $300 \mathrm{~mL}$ Erlenmeyer then added $125 \mathrm{~mL}$ of $3.5 \%$ nitric acid solution and heated in a water bath for 12 hours at $80^{\circ} \mathrm{C}$. The sample was filtered and washed with distilled water until colorless and then air dried. The colorless sample was transferred into the Erlenmeyer and added a $125 \mathrm{ml}$ mixture of $\mathrm{NaOH}$ and $\mathrm{Na}_{2} \mathrm{SO}_{3}(20 \mathrm{~g}: 20 \mathrm{~g}$ in $1 \mathrm{~L}$ water) and heated for 2 hours at $50^{\circ} \mathrm{C}$. The mixture was filtered and washed with distilled water until the filtrate was colorless. A $50 \mathrm{~mL}$ of $10 \%$ sodium chlorite solution was added and washed with water until a white precipitate was obtained. A $100 \mathrm{~mL} \mathrm{10 \%} \mathrm{acetic} \mathrm{acid} \mathrm{was} \mathrm{added} \mathrm{and}$ washed until acid-free. The sample was then dried in an oven at $103 \pm 2{ }^{\circ} \mathrm{C}$ until fixed weight achieved. The cellulose content in the samples was calculated as cellulose (\%) to whole sampel dry weight sampel.

\subsection{Hemicellulose}

Determination of hemicellulose content was done triplicates based on a reduction of the holocellulose 
and cellulose contents (modified from Southon \& Magana, 2010; Carvalheiro, Duarte, \& Gírio, 2008).

\subsection{Ash}

The ash determination was performed using TAPPI T211 om-02 (2002) procedure. Ash shows the content of residual inorganic material after burning of organic matter. The main components of wood ash are calcium, potassium, and magnesium. Minor components are such as manganese, sodium, and phosphor. Determination of ash begins with cleaning and heating empty ash porcelain crucibles at $525 \pm$ $25^{\circ} \mathrm{C}$ for 30 minutes. Then $1 \mathrm{~g}$ of sample was weighed in a porcelein crucible, and heated at $100^{\circ} \mathrm{C}$ in furnace then slowly increased the temperature to $525 \pm 25^{\circ} \mathrm{C}$ until the carbonation occurred without burning. The process was completed when the black particles was disappeared. The crucibles were cooled in the desiccator and then weighed them until constant weight achieved (TAPPI T211 om-02, 2002).

\subsection{Insoluble Acid Ash}

The ash obtained from the above 2.6 analysis was transferred into $250 \mathrm{~mL}$ Erlenmeyer and added $25 \mathrm{~mL}$ of $10 \% \mathrm{HCL}$ solution. The ash was boiled for 5 minutes, sieved with a specific filter paper then rinsed with distilled water several times until pH 7.0 achieved. The filter paper was transferred to porcelein crucible and then inserted it into the furnace at $100{ }^{\circ} \mathrm{C}$ and slowly increased to $525 \pm 25^{\circ} \mathrm{C}$. Cool and weigh until constant weight achieved with tolerable different range not more than $0.002 \mathrm{~g}$ (TAPPI T211 om-02, 2002). This value, recorded as \% Insoluble acid ash. It was used to convert the weight ash sample after extraction to dry weight sample (whole sample).

\subsection{Moisture Content}

Determination of moisture content was calculated by gravimetric based on sample weight before and after drying. The basic principle of moisture determination was that water molecules were removed by heating using a vacuum oven at $95-100^{\circ} \mathrm{C}$ and keep the air pressure not more than $100 \mathrm{mmHg}$ for 5 hours (TAPPI 207 om-99, 1999).

\subsection{Extractives Substances}

The determination of extractive substance was carried out using TAPPI 207 om-97 (1997). This method measures the solubility of an ingredient in water. Extractive substances are chemical compounds with water-soluble molecular materials.
Generally, the extractive content in non-wood raw materials is higher than the wood of broad leaves and pin wood. Water-soluble extractives include sugar, pectin, starch, tannins, gums, dye, and organic salts. A $2 \pm 0.1 \mathrm{~g}$ sample was placed at $250 \mathrm{~mL}$ Erlenmeyer and added $100 \mathrm{~mL}$ hot aquabides water, then placed in water bath for 3 hours. The water surface of water bath should exceed the water level in Erlenmeyer.

The sample was transferred into a dried glass filter at $105 \pm 3^{\circ} \mathrm{C}$ until the weight was constant. The sample was then washed with $200 \mathrm{~mL}$ hot water and dried at $103 \pm 2{ }^{\circ} \mathrm{C}$ until constant weight was obtained (TAPPI 204 om-97, 1997). The extractive content in the samples was calculated using the following formula. Extractives substances $(\%)=((A-B) / A) x$ 100. This value, recorded as $\%$ extractives, can be used to convert the dry weight sample after extraction (B) reported on a extractives-free basis to an (A) as Dry weight sample (whole sample).

\subsection{Fourier Transform Infra-Red (FTIR) Analysis}

FTIR analysis was performed using $\mathrm{KBr}$ pellet method. Samples consisting of agar solid waste, cellulose standard (Sigma) and celite standards were $2 \mathrm{mg}$ each crushed in a small mortar with $100 \mathrm{mg}$ of dried $\mathrm{KBr}$ crystals. The homogenous mixture was placed between two key-mounted screws. The two screws were then opened and pressed to produce a thin disc of $1 \mathrm{~cm}$ in diameter by mini hand press tool. The $\mathrm{KBr}$ thin sample disc was placed in the infrared spectrophotometer cell with a hole leading to the radiation source (Perkin Elmer). Data were collected over the range of $4000-450 \mathrm{~cm}^{-1}$ with a $4 \mathrm{~cm}^{-1}$ spectral resolution, and 32 scans were taken per sample (modified from Liu \& Kim, 2017).

\section{Results and Discussion}

\subsection{Characteristic of Solid Waste from Agar Industry}

The dried solid waste of the agar industry was visually similar to pumice stone (Figure 1). Agar is known to be made from red seaweed Gracilaria verrucosa, in which celite was added during the process. Thus, the waste contains pienty of celite as well. Celite is commonly used as a filter (filtration media) because it has a high porosity of many small holes. Celite is a mineral that has a composition similar to diatomic soils consisting of silica and alumina. Celite being low polarity and wide adhesion is an inorganic material that is cheap and easy to 


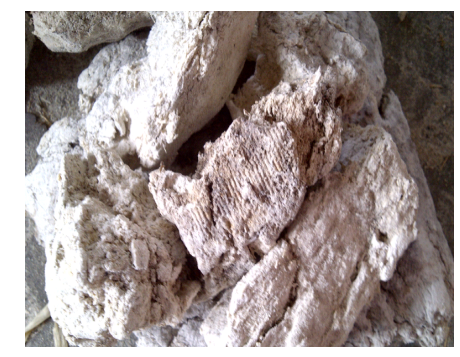

Figure 1. Solid waste from the agar industry
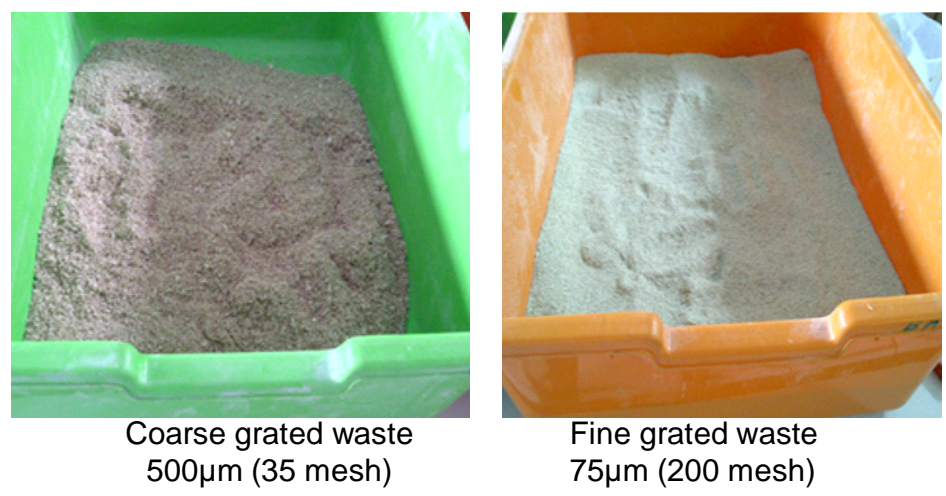

Figure 2. Agar solid waste that has been grated

obtain. Therefore, it is widely used as a filter and also for the immobilization of some active compounds (Ansari \& Husain, 2012).

The solid waste resembled stone and needed to reduce the size from $500 \mu \mathrm{m}$ (35 mesh) to $75 \mu \mathrm{m}$ (200 mesh) (Figure 2). This size reduction caused an increase in the surface area of the substrate. A total of $1.6 \mathrm{~kg}$ celite was separated from $20 \mathrm{~kg}$ weight of agar solid waste, and the rest was 35 mesh size $(500 \mu \mathrm{m})$ seaweed waste. It was estimated that $8 \%$ of solid waste was celite. The size of coarse solid fiber particle was 35 mesh and then reduced to 200 mesh $(75 \mu \mathrm{m})$. Agar was removed by the addition of water into 200 mesh solid wastes, then boiled and cooled. Finally, agar can be separated.

Kumar, S., Gupta, R., Kumar, G., Sahoo, D., and Kuhad, R.C. (2013) reported that fresh seaweed processed into agar produced waste with $62-68 \%$ holocellulose content. Meanwhile, the waste still contains cellulose (Marinho-Soriano, 2001; MarinhoSoriano \& Bourret, 2005) and the amount is approaching 40\% (Kumar et al., 2013). The solid waste from agar processing industries in Indonesia (domestic scale) has been explored to be used as a raw material for bioethanol (Anggarawati, 2012; Rahmadini, 2012; Martosuyono, Munifah, \& Ningrum, 2016) processed by using strong acids, thermal treatment, commercial enzymes, as well as the addition of the Trichoderma resei, and Saccharomyces cerevisiae (John, Anisha,
Nampoothiri, \& Pandey, 2011; Kim et al. 2011, 2012, 2013; Yanagisawa, Nakamura, Ariga, \& Nakasaki, 2011; Ruiz, Jasso, Fernandes, Vicente, \& Teixeira, 2013).

Seaweed consists of various soluble and insoluble organic compounds, such as agar, alginate, carrageenan, glucose, galactose, mannitol, rhamnose, cellulose, and hemicellulose. Most organic and inorganic compounds will be washed out during the phycocolloid extraction process. Residues in the form of agar solid waste containing cellulose, hemicellulose, and insoluble ash are the main components that can be used as feedstock for enzyme production (Table 1). Stiger-Pouvreau et al. (2016) conclude that most seaweed consists of 50$60 \%$ carbohydrate component.

Solid waste from the processing of Gracilaria showed high cellulose content. Low lignin content in the agar solid waste made it possible to be utilized for an alternative renewable material, e.g. as a substrate in the production of cellulase. The presence of cellulose in the waste allows it to be used as a source of energy or raw material for the manufacture of high value products. Cellulose is one of the carbohydrate components found in that solid waste. Cellulose is the structural framework of all plants and a major part of plant cell wall which composed of up to 10.000 units of glucose in the form of hydro glycopiranous units with the formula $\left[\mathrm{C}_{6} \mathrm{H}_{10} \mathrm{O}_{5}\right]_{\mathrm{n}}$. The cell wall of red 
Table 1. Composition of solid waste agar from CV. Agar Sari Jaya Malang

\begin{tabular}{lc}
\hline \multicolumn{1}{c}{ Component } & $(\mathbf{w} / \mathbf{w})(\%)^{*}$ \\
\hline Lignin & 2.08 \\
Holocellulosa & 38.83 \\
Cellulosa & 28.19 \\
Hemicellulose & 10.63 \\
Ash & 8.27 \\
Insoluble acid ash & 3.54 \\
Water & 11.23 \\
Extractives substances & 1.621 \\
\hline
\end{tabular}

${ }^{*}$ Note: Result of 2 measurements average

seaweed consists of cellulose, agar, xylan, and carrageenan (Wijengsihe \& Jeon, 2012). The difference in cell wall composition makes seaweed more potential as a source of cellulose than terestrial plants. Another possible application of cellulose is as textile fibers that have potential to compete with synthetic fibers. For wider applications, cellulose can produce several derivative products, including Microcrystalline Cellulose, Carboxymethylcellulose, Methylcellulose and Hydroxypropyl Methylcellulose. These products are utilized, among others, as an emulsifier, stabilizer, thickener, dispersing, and gelling agent.

Microorganisms, just like other living things are also require source of energy in the form of carbon, nitrogen, oxygen, iron, and some other minerals. The energy source required can come from both nutritional sources in the form of synthetic and semi-synthetic media. On laboratory scale, synthetic and nonsynthetic media can be used, but on an large industrial scale, the use of synthetic and non-synthetic media is uneconomical, therefore another alternative source of energy being cheap and easy to obtain such as agricultural waste has to be explored (Nair, 2010).

The carbon sources used in culture media such as carbohydrates, sugars, proteins, and lipids can act as energy sources for the growth, carbon skeleton for the synthesis of various biological compounds and metabolism of the microbial cells (Nair, 2010). The effect of various natural carbon sources like fruit juices was investigated as alternative carbon sources for bacterial cellulose production by Gluconacetobacter persimmonis GH-2 (Hungund et al., 2013).

\subsection{FT-IR Spectral Collection and Data Analysis}

FT-IR is an instrument using spectroscopic principles equipped with a Fourier transform for detection and analysis of spectral profiles. Infrared spectroscopy is useful for the identification of a compound because each functional group on the compound provides infrared light at a unique frequency.

The agar solid waste, were observed using FTIR, in order to obtain spectral profiles of cellulose separation from agar industrial waste. The FTIR analysis is also directed to determine the differences between functional groups contained in the cellulose standard of SIGMA and agar solid waste.

Infrared spectrum of the agar solid waste sample gave the important functional groups appearing at wave numbers of $3500.05 ; 2916.24 ; 2145.54 ; 1160.49$; 1424.49; 1374.89; 1053.03; 707.66; and $896.85 \mathrm{~cm}^{-1}$. The infrared spectra of standard showed crucial functional groups appearing at wave numbers of $3527.96 ; 2912.80 ; 2155.91 ; 1643.35 ; 1050.00$; and $786.98 \mathrm{~cm}^{-1}$ (Figure 3, Table 2).

The major peak uptake on the standard celite that was also found in the agar solid waste spectra was at $2342.58 \mathrm{~cm}^{-1}$. The wave numbers appearing in the range of $2380-2080 \mathrm{~cm}^{-1}$ indicate the presence of $\mathrm{Si}$ and $\mathrm{H}$ bonds. The other major absorption appearing in the range of wave numbers of $1110-830 \mathrm{~cm}^{-1}$ showed the presence of $\mathrm{Si}$ and $\mathrm{O}$ bonds.

This absorption appeared very strong at the standard celite at the wave number of $793.68 \mathrm{~cm}^{-1}$ and $772.99 \mathrm{~cm}^{-1}$ for sample solid agar waste as shown in Figure 4 and Table 2. The existence of the peak appearing on the wave number of $3600-3100 \mathrm{~cm}^{-1}$ was suspected as the -OH stretching group providing the hydrogen bonding information, in which the range at this wave number was characteristic of the cellulose FTIR spectra (Ciolacu, Ciolacu, \& Popa, 2011).

With respect to infrared spectrum for standard cellulose samples, the $-\mathrm{OH}$ group was recorded at wave number of $3527.96 \mathrm{~cm}^{-1}$, while the $-\mathrm{OH}$ asolid waste of agar-agar group was observed at 3500.05 $\mathrm{cm}^{-1}$. Ciolacu et al. (2011) conclude that the peak appearing on the wavelength $2900 \mathrm{~cm}^{-1}$ was the $\mathrm{C}-\mathrm{H}$ stretching group. 


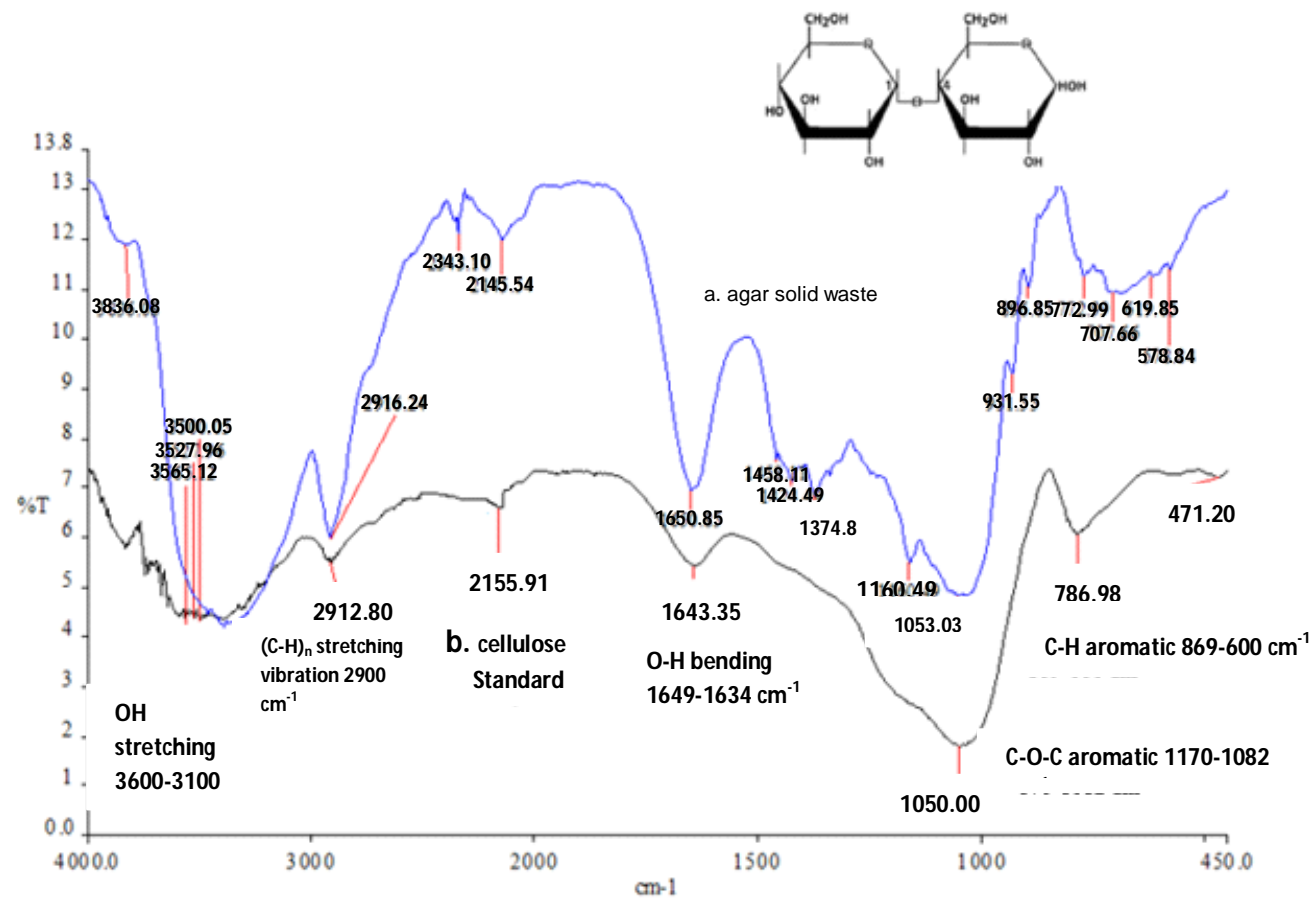

Figure 3. Infrared spectrum overlay between spectra a. agar solid waste and b. cellulose standard (Sigma).

Tabel 2. Characteristic infrared bands of standard celite and solid waste of agar spectra

\begin{tabular}{lcccc}
\hline \multicolumn{1}{c}{ Band Assignment } & Useful range $\left.\mathbf{( c m}^{-1}\right)$ & $\begin{array}{c}\text { Wave number }\left(\mathbf{c m}^{-1}\right) \\
\text { Solid agar } \\
\text { waste }\left(\mathbf{c m}^{-1}\right)\end{array}$ & $\begin{array}{c}\text { Cellulosa standar } \\
\left(\mathbf{c m}^{-1}\right)\end{array}$ & $\begin{array}{c}\text { Celite standar } \\
\left(\mathbf{c m}^{-1}\right)\end{array}$ \\
\hline$-\mathrm{OH}$ stretching & $3600-3100$ & 3500.05 & 3527.96 & \\
$(\mathrm{C}-\mathrm{H})_{\mathrm{n}}$ stretching vibration & 2900 & 2916.24 & 2912.8 & \\
$\mathrm{OH}$ bending & $1649-1634$ & 1650.85 & 1643.35 & \\
$\mathrm{C}-\mathrm{OC}$ cincin piranosa & $1170-1082$ & 1160.49 & 1152.3 & \\
$\mathrm{C}-\mathrm{OH}$ & 1060 & 1053.03 & 1050 & \\
$\mathrm{C}-\mathrm{H}$ aromatis & $869-600$ & 707.66 & 786.98 & 2342.58 \\
$\mathrm{Si}-\mathrm{H}$ & $2380-2080$ & 2343.45 & & 793.68 \\
$\mathrm{Si}-\mathrm{O}$ & $1110-830$ & 772.99 & & \\
\hline
\end{tabular}

The stretching vibration $\mathrm{C}-\mathrm{H}$ group emerged on the wave number of $2916.24 \mathrm{~cm}^{-1}$ for the agar solid waste standard and $2912.8 \mathrm{~cm}^{-1}$ for the standard cellulose.

According to Oh, S.Y., Yoo, I., Shin, Y., and Seo, G. (2005) peaks that emerger in the range of 4000$2995 ; 2900 ; 1430 ; 1375$; and $900 \mathrm{~cm}^{-1}$ were a typical functional group area representing the crystalline or amorphous sample. The peak absorption at the wave number of $1430 \mathrm{~cm}^{-1}$ indicated the crystallinity of a sample. The typical crystallinity uptake emerged at wave numbers of $1424.49 \mathrm{~cm}^{-1}$ in the solid waste of agar-agar sample (Figure 3 and Figure 4).

The peak absorption apearing in the range of 1170 $1082 \mathrm{~cm}^{-1}$ showed the bonding $\mathrm{C}-\mathrm{OC}$ stretching in the $1.4 \beta$ glucosidic bond (Yang, 2007; Moran, Alvarez, Cyras, \& Vasquez, 2008; Ciolacu et al., 2011). The solid waste of agar-agar sample provided peak absorption at wave numbers of $1160.49 \mathrm{~cm}^{-1}$. The hydrogen bonds of $\mathrm{C}-\mathrm{H}$ aromatic pyranose ring emerged both in the agar solid waste cellulose and 


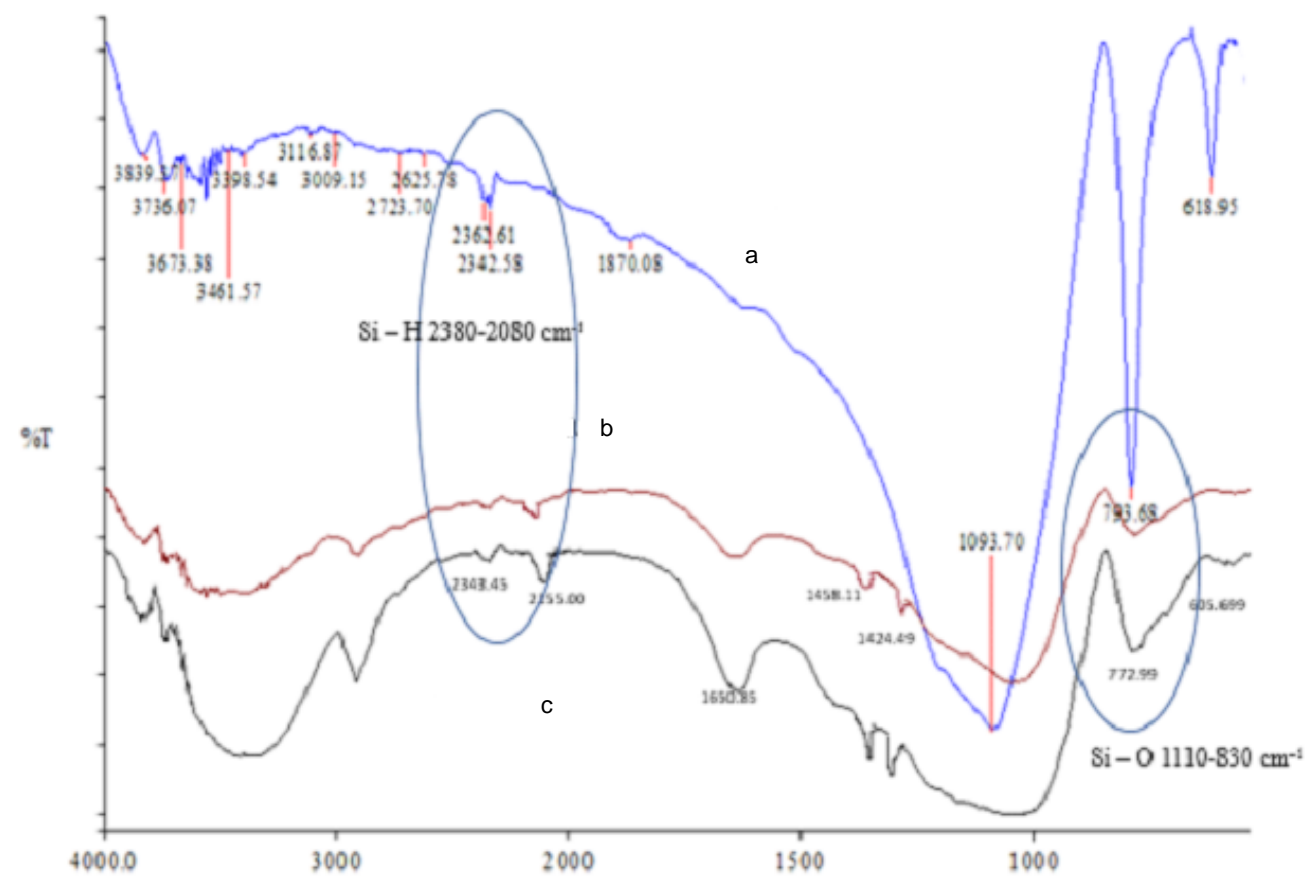

Figure 4. Infrared spectrum overlay between a. Standard celite; b. agar solid waste 35 mesh; and c. agar solid waste 200 mesh.

standard cellulose samples at wavelength of 707.6 $\mathrm{cm}^{-1}$ and $786.98 \mathrm{~cm}^{-1}$ respectively (Yang, 2007). The spectral profile of cellulose separation from industrial waste showed that the agar solid waste sample had an absorption peak similar to that of the absorption peak on the cellulose standard.

The solid waste of agar-agar sample had a lot of celite, which was demonstrated by the presence absorption peak occuring at wave number of 2343.45 $\mathrm{cm}^{-1}$ for the absorption of the $-\mathrm{Si}-\mathrm{H}$ bond and at the wave number of $772.99 \mathrm{~cm}^{-1}$ from the bond -Si- O-. Infra red spectra showed that celite was still found in solid waste agar solid waste. The results also informed that there was a peak reinforcing that there was still a large amount of cellulose content in solid waste agar solid waste, and expressed an uptake similar to the absorption provided by standard cellulose.

\section{Conclusion}

The solid waste of the agar-agar industry had high cellulosic content that might be used as an alternative carbon for renewable material. For wider applications, cellulose can generate several products, such as Microcrystalline Cellulose, Carboxymethylcellulose, Methylcellulose and hydroxypropyl methylcellulose. The remaining components in agar solid waste were $53.53 \%$ of total cellulose fibers, $37.33 \%$ agar and $8.60 \%$ celite.

\section{Acknowledgment}

This research was supported by funding from the Research and Development Center for Marine and Fisheries Product Processing and Biotechnology.

\section{References}

[FAO] Food and Agriculture Organization of the United Nations. (2012). FAO Statistical Yearbook 2012: World Food and Agriculture. [Internet]. [downloaded 2013 Des 6]. Available in www.fao.org/icatalog/inter-e.htm Anggarawati, D. (2012). Activity of Cellulase Enzyme from Isolate SGS 2609 BBP4BKP using diluted aci pretreated seaweed waste as substrate [Tesis]. Depok (ID): Universitas Indonesia.

Ansari, S.A., \& Husain, Q. (2012). Lactose hydrolysis from milk/whey in batch and continuous processes by concanavalin A-Celite 545 immobilized Aspergillus oryzae $\beta$ galactosidase. Food Bioprod Process. 90:351-359. doi:10.1016/j.fbp.2011.07.003

Carvalheiro, F., Duarte, LC., \& Gírio, F.M. (2008). Hemicellulose biorefineries: a review on biomass pretreatments. J sci ind res 67:849-864.

Ciolacu, D., Ciolacu, F., \& Popa, V. (2011). Amorphous cellulose-structure and characterization. Cellulose Chem Technol. 45:13-21.

Hungund, B., Prabhu, S., Shetty, C., Acharya, S., Prabhu, V., \& Gupta, S.G. (2013). Production of bacterial cellulose from gluconacetobacter persimmonis $\mathrm{GH}$ 2 using dual and cheaper carbon sources. J. Microb. 
Biochem.Technol 5:2 http://dx.doi.org/10.4172/19485948.1000095

Jang J., Cho Y., Jeong G., \& Kim, S. (2012). Optimization of sacharification and ethanol production by simultaneous saccharification and fermentation (SSF) from seaweed Saccharina japonica. Bioproc Biosyst Eng. 35:11-18.

John, R.P., Anisha, G.S., Nampoothiri, K.M., \& Pandey, A. (2011). Micro and macroalgal biomass: A renewable source for bioethanol. Biores Technol. 102:186-193.

Kim G.S., Myung K.S., Kim Y.J., Oh K.K., Kim J.S., Ryu H.J., \& Kim K.H. (2008). Methods of producing biofuel using sea algae. Seoul (KR): World Intellectual Property Organization.

Kim, H.T., Lee, S., Kim, K.H., \& Choi, I.G. (2012). The complete enzymatic saccharification of agarose and its application to simultaneous saccharification and fermentation of agarose for ethanol production. Biores Technol. 107:301-306.

Kim, H.T., Yun, EJ., Wang, D., Chung, J.H., Choi, I.G., \& Kim, K.H. (2013). High temperature and low acid pretreatment and agarase treatment of agarose for the production of sugar and ethanol from red seaweed biomass. Biores Technol. 136:582-587. https://doi.org/10.1016/j.biortech.2013.03.038

Kim, N.J., Li, H., Jung, K., Chang, H.N., \& Lee, P.C. (2011). Ethanol production from marine algal hydrolysates using Escherichia coli KO11. Biores Technol. 102:7466-7470.

Kumar, S., Gupta, R., Kumar, G., Sahoo, D., \& Kuhad, R.C. (2013). Bioethanol production from Gracilaria verrucosa, a red alga, in a biorefinery approach. Biores Technol. 135: 150-156. http://dx.doi.org/ 10.1016/j.biortech.2012.10.120

Lee J.Y., Li P., Lee J., Ryu H.J., \& Oh K.K. (2013). Ethanol production from Saccharina japonica using an optimized extremely low acid pretreatment followed by simultaneous saccharification and fermentation. Biores Technol. 127:119-125. http://dx.doi.org/ 10.1016/j.biortech.2012.09.122

Liu, Y., \& Kim, H.J. (2017). Fourier transform infrared spectroscopy (FT-IR) and simple algorithm analysis for rapid and non-destructive assessment of developmental cotton fibers. Sensors. 17(7):1469. doi:10.3390/s17071469 www.mdpi.com/journal/ sensors.

Marinho-Soriano, E. (2001). Agar polysaccharides from Gracilaria species Rhodophyta (Gracilariaceae). J Biotechnol. 89:81-84.

Marinho-Soriano, E,. \& Bourret, E. (2005). Polysaccharides from the red seaweed Gracilaria dura (Gracilariales, Rhodophyta). Biores Technol. 96:379-382.

Martosuyono, P., Munifah, I., \& Ningrum G.A. (2016). Ethanolic fermentation efficiency of seaweed solid waste hydrolysates by Saccharomyces cerevisiae. Squalene Bull. Mar. Fish. Postharvest Biotech. 11(1):712. DOI: http:dx.doi.org/10.15578/squalene. v11 i1.231.

Moran, J.I., Alvarez, V.A., Cyras, V.P., \& Vasquez, A. (2008). Extraction of cellulose and preparation of nanocellulose from sisal fibers. Cellulose. 15:149159. DOI 10.1007/s10570-007-9145-9.

Nair, J.A. (2010). Comprehensive biotechnologi XI. Laxmi Publication Pvt. Ltd.

Oh, S.Y., Yoo, I., Shin, Y., \& Seo, G. (2005). FTIR analysis of cellulose treated with sodium hydroxide and carbon dioxide 340. 417-428. http://doi.org/10.1016/ j.carres.2004.11.027.

Rahmadini, I. (2012). Purification and Characterization of cellulase from bacteria isolated from seaweed [Thesis]. Bogor (ID): Institut Pertanian Bogor.

Ruiz, H.A., Jasso, R.M., Fernandes, B..D., Vicente, A.A., \& Teixeira, J.A. (2013). Hydrothermal processing, as an alternative for upgrading agriculture residues and marine biomass according to the biorefinery concept: A review. Renew Sustainable Energy Rev. 21:35-51.

Southon, J.R. \& Magana, A.L. (2010). A comparison of cellulose extraction and aba pretreatment methods for ams 14c dating of ancient wood. Proceedings of the 20th International Radiocarbon Conference, University of Arizona. 52: 1371-1379.

Stiger-Pouvreau, VS., Bourgougnon, N., \& Deslandes, E. (2016). Carbohydrates From Seaweeds. Book: Seaweed in Health and Disease Prevention. Elsevier Inc. dx.doi.org/10.1016/B978-0-12-802772-1.000087.

TAPPI 204 om-97. (1997). Determination of extractive substance. Accessed from http://www.tappi.org

TAPPI 207 om-99. (1999). Determination of water content in wood. Accessed from http://www.tappi.org

TAPPI T211 om-02. (2002). Ash in wood, pulp, paper and paperboard. Accessed from http://www.tappi.org

TAPPI T222 om-02. (2006). Acid-insoluble lignin in wood and pulp accessed from http://www.tappi.org

Wijengsihe, W.A.J.P. \& Jeon, Y.J. (2012). EnzymeAssistant Extraction (EAE) of bioactive component: a useful approach for recovery of industrially important metabolites from seaweeds: A review. Fitoterapia. 83:6-12.

Yanagisawa, M., Nakamura, K., Ariga, O., \& Nakasaki, K. (2011). Production of high concentrations of bioethanol from seaweeds that contain easily hydrolyzable polysaccharides. Process Biochem. 46: 2111-2116.

Yang, H. (2007). Characteristics of hemicellulose, cellulose and lignin pyrolysis. Fuel. 86, 1781-1788. http://doi.org/10.1016/j.fuel.2006.12.013. 